\title{
Effect of perimuscular injection of Bothrops jararacussu venom on plasma creatine kinase levels in mice: influence of dose and volume
}

\footnotetext{
S. Calil-Elias ${ }^{1}$,

E. Thattassery ${ }^{1,3}$

A.M.B. Martinez ${ }^{2}$

and P.A. Melo ${ }^{1}$
}

\author{
Departamentos de ${ }^{1}$ Farmacologia Básica e Clínica, and \\ ${ }^{2}$ Histologia e Embriologia, Instituto de Ciências Biomédicas, \\ Universidade Federal do Rio de Janeiro, Rio de Janeiro, RJ, Brasil \\ ${ }^{3}$ School of Medicine, University of Maryland at Baltimore, Baltimore, MD, USA
}

\section{Correspondence \\ P.A. Melo \\ Departamento de Farmacologia \\ Básica e Clínica \\ ICB, CCS, UFRJ \\ 21941-560 Rio de Janeiro, RJ \\ Brasil \\ Fax: +55-21-280-4694 \\ E-mail: pamelo@ farmaco.ufrj.br \\ Presented at the XVI Annual Meeting of the Federação de Sociedades de Biologia Experimental, Caxambu, MG, Brazil, August 29 - September 1, 2001 \\ Research supported by CNPq, CAPES, Fundação Universitária José \\ Bonifácio (FUJB, UFRJ), FAPERJ, \\ PRONEX and Fogarty Minority \\ International Research Training \\ Program.}

Received April 20, 2001

Accepted August 6, 2002

\section{Abstract}

The effect of dose and volume of a perimuscular injection of Bothrops jararacussu venom on myonecrosis of skeletal muscle was studied in mice. An increase of the venom dose $(0.25$ to $2.0 \mu \mathrm{g} / \mathrm{g})$ at a given volume $(50 \mu \mathrm{l})$ resulted in an increase in plasma creatine kinase $(\mathrm{CK})$ levels $2 \mathrm{~h}$ after injection. Plasma CK activity increased from the basal level of $129.27 \pm 11.83(\mathrm{~N}=20)$ to $2392.80 \pm 709.43 \mathrm{IU} / \mathrm{l}(\mathrm{N}=4)$ for the $1.0 \mu \mathrm{g} / \mathrm{g}$ dose. Histological analysis of extensor digitorum longus muscle $4 \mathrm{~h}$ after injection showed lesion of peripheral muscle fibers, disorganization of the bundles or the complete degeneration of muscle fibers. These lesions were more extensive when higher doses were injected. Furthermore, an increase in volume $(12.5$ to $100 \mu \mathrm{l})$ by dilution of a given dose $(0.5 \mu \mathrm{g} / \mathrm{g})$ also increased plasma CK levels from $482.31 \pm 122.79$ to $919.07 \pm 133.33 \mathrm{IU} / \mathrm{l}(\mathrm{N}=4)$, respectively. These results indicate that care should be taken to standardize volumes and sites of venom injections.
Local myonecrosis is a serious manifestation of snake bites causing prolonged and sometimes permanent disability. A number of snake venoms induce histological alterations when injected into or close to muscle tissue (1-5). The myotoxic activity of snake venoms can be monitored by the increase of plasma creatine kinase (CK) activity and morphological analysis. The increase in plasma CK levels results from sarcolemmal damage due to myotoxic components of the venom (1-3,6-10).

In the present study, by using a different method to inject the crude venom over the

\section{Key words}

- Bothrops venoms

- Myotoxicity

- Skeletal muscle

- Plasma creatine kinase muscle tissue rather than directly into it, we investigated whether not only the dose, but also the volume of the venom injected can affect plasma CK activity. Adult Swiss mice (20-25 g) were lightly anesthetized with diethyl ether and injected with four different doses of Bothrops jararacussu crude venom $(0.25-2.0 \mu \mathrm{g} / \mathrm{g})$ in a final volume of $50 \mu \mathrm{l}$. The solution was positioned over the extensor digitorum longus (EDL) muscle. The venom was not injected directly into the muscle as previously described (7-10), but was inoculated under the tibial anterior muscles and the tibia, close to the external 
surface of the EDL muscle. Thus, the venom solution should have surrounded the whole muscle, bathing the epimysium and the gutter where the muscle works. In addition, the venom was applied at the single dose of 0.5 $\mu \mathrm{g} / \mathrm{g}$ in four volumes, 12.5, 25.0, 50.0 and $100.0 \mu 1$. Venom was diluted in physiological saline $(\mathrm{NaCl})$. Myotoxicity is reported as an increase in plasma CK activity.

Blood samples were collected before and $2 \mathrm{~h}$ after venom injection. The serum was separated and stored at $4^{\circ} \mathrm{C}$ for subsequent determination of plasma $\mathrm{CK}$ activity using a diagnostic kit(Diagnostica Merck, São Paulo, SP, Brazil). Enzyme activity is reported as $\mathrm{IU} / 1$, where $1 \mathrm{IU}$ is the amount that catalyzes the transformation of $1 \mu \mathrm{mol}$ of substrate (NADH) per min at $25^{\circ} \mathrm{C}(2)$. Basal plasma CK activity was that obtained for the blood samples from each group collected before the injection of either venom or $\mathrm{NaCl}$.

Figure 1. Effects of dose and volume on in vivo myotoxicity of Bothrops jararacussu venom in mice. A, The venom protein dose was increased from 0.5 to $2.0 \mu \mathrm{g} / \mathrm{g}$ in the same volume (50 $\mu \mathrm{l})$. Plasma creatine kinase (CK) levels were measured $2 \mathrm{~h}$ after venom injection. $B$, Effect of injection volume. Venom, $0.5 \mu \mathrm{g} / \mathrm{g}$ was injected in increasing volumes, 12.5 to $100 \mu \mathrm{l}$, and plasma CK levels were measured $2 \mathrm{~h}$ after injection. In both protocols the control group received $50 \mu \mathrm{l}$ of $0.9 \% \mathrm{NaCl}$. Data are reported as means \pm SEM $(\mathrm{N}=4)$. $* \mathrm{P}<0.05$ compared to the control group (ANOVA).

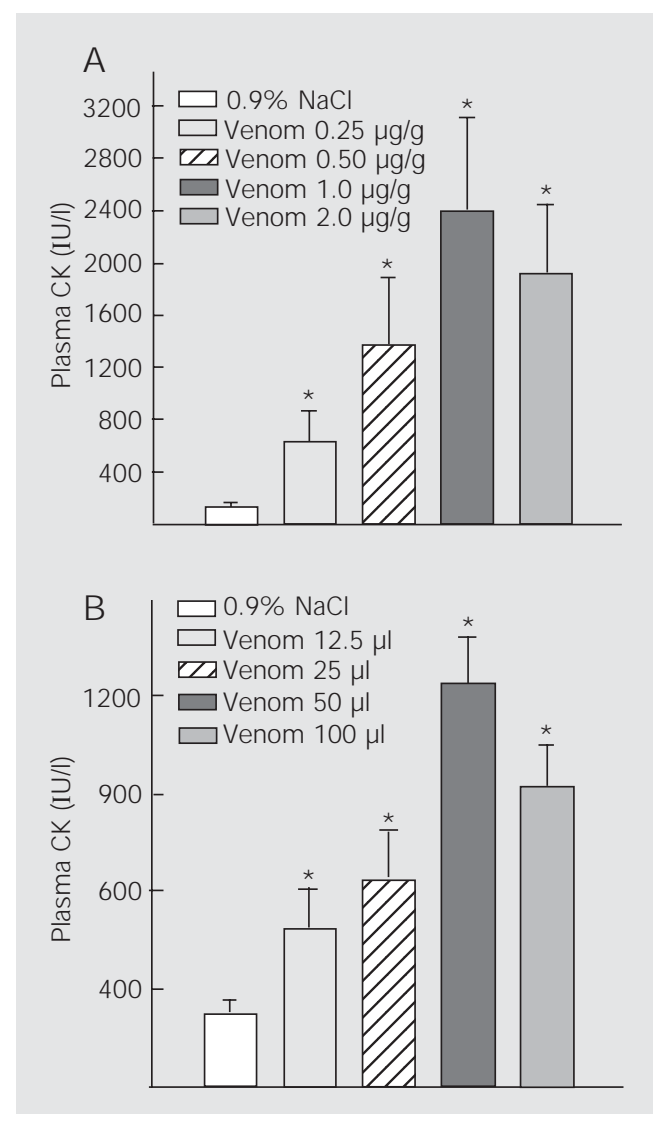

Histological analysis was performed $4 \mathrm{~h}$ after venom injection. The mice were killed under ether anesthesia and the right posterior EDL muscles were dissected. Fragments of this muscle were immersed in fixative solution (4\% paraformaldehyde and $2 \%$ glutaraldehyde in $0.1 \mathrm{M}$ sodium cacodylate buffer, $\mathrm{pH}$ 7.4) for 2 to $4 \mathrm{~h}$. The fragments were then washed in buffer and fixed again for $1 \mathrm{~h}$ in $1 \%$ aqueous $\mathrm{OsO}_{4}$. The tissue was dehydrated in acetone and embedded in Polybed 812 resin. Semi-thin sections $(500 \mathrm{~nm})$ were obtained for light microscopy and stained with $1 \%$ toluidine blue $(1,3,5)$.

Figure 1A shows the effect of increasing the concentration of the dose of the $B$. jararacussu venom on plasma CK levels. CK activity increased from the basal level of $129.27 \pm 11.83(\mathrm{~N}=20)$ to $618.30 \pm 242.98$ IU/l $(\mathrm{N}=4)$ for the $0.25 \mu \mathrm{g} / \mathrm{g}$ dose and up to $2392.80 \pm 709.43 \mathrm{IU} / \mathrm{l}(\mathrm{N}=4)$ for the $1.0 \mu \mathrm{g} /$ $\mathrm{g}$ dose. Doses higher than $1.0 \mu \mathrm{g} / \mathrm{g}$ induced the maximum effect (data not shown). These results indicate that plasma CK levels depend on the doses of venom. It is interesting to note that plasma $\mathrm{CK}$ activity was lower $(1917.90 \pm 530.47 \mathrm{IU} / \mathrm{l}, \mathrm{N}=4)$ at $2.0 \mu \mathrm{g} / \mathrm{g}$, but not significantly different from the activity observed at the dose of $1.0 \mu \mathrm{g} / \mathrm{g}(2932.50$ $\pm 709.43 \mathrm{IU} / \mathrm{l}, \mathrm{N}=4$ ) of $B$. jararacussu venom. One possible explanation for this plateau of plasma CK activity is the interplay of local venom effects. Although the amount of CK released from the damaged muscle was greater, the local hemorrhage, edema and local stasis caused by the venom did not allow the washout of $\mathrm{CK}$ to the capillaries.

Figure 1B shows the effect of a single dose, $0.5 \mu \mathrm{g} / \mathrm{g}$ of $B$. jararacussu venom injected in four different volumes, 12.5, 25.0, 50.0 , and $100.0 \mu 1$ on plasma CK levels. The injection of $0.5 \mu \mathrm{g} / \mathrm{g}$ of the venom dissolved in $12.5 \mu 1 \mathrm{NaCl}$ increased basal plasma CK activity from $128.53 \pm 19.65 \mathrm{IU} / \mathrm{l}(\mathrm{N}=20)$ to $482.31 \pm 122.79 \mathrm{IU} / \mathrm{l}(\mathrm{N}=4)$, while the injection of the same dose of the venom dissolved in $50 \mu \mathrm{l} \mathrm{NaCl}$ increased $\mathrm{CK}$ activ- 
ity to $1239.95 \pm 144.85 \mathrm{IU} / 1(\mathrm{~N}=4)$, showing an increase in plasma CK activity in a volume-dependent fashion. A plausible mechanism for the increased lesion occurring with increasing injection volumes is that the venom comes into contact with a larger area surrounding the muscle, and is thus able to reach and affect more muscle fibers. However, we cannot explain why 100 $\mu \mathrm{l}$ did not result in the highest CK activity.

Figure 2A-C demonstrates the effects of increasing venom doses on the histology of muscle fibers. The figure shows a panoramic view of transverse sections of EDL muscle 4 $\mathrm{h}$ after receiving $50 \mu \mathrm{l}$ injections of $\mathrm{NaCl}$ (Figure $2 \mathrm{~A}$ ), $0.25 \mu \mathrm{g} / \mathrm{g}$ of venom (Figure $2 \mathrm{~B}$ ), and $2.0 \mu \mathrm{g} / \mathrm{g}$ of venom (Figure $2 \mathrm{C}$ ). These data suggest that increasing concentrations of venom result in increasing muscle lesions, and further demonstrate that increasing volumes of the injection can also increase these lesions and plasma CK levels. These results indicate that care must be taken in standardizing and reporting injection doses and volumes in future studies to ensure consistency and reliability of the experimental conditions.

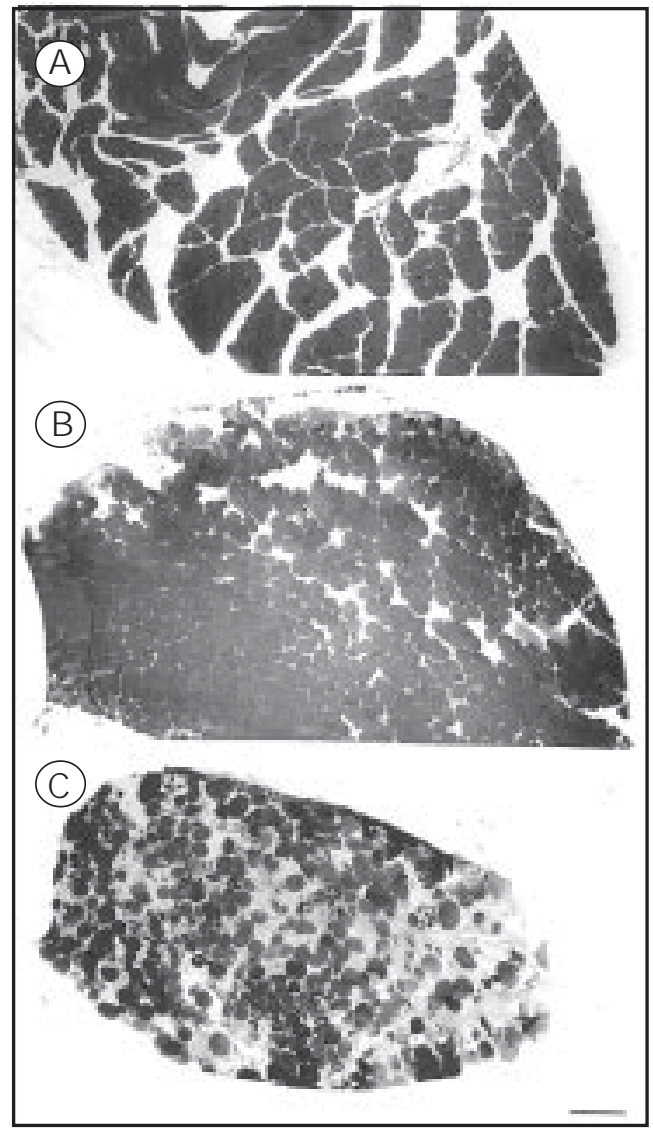

Figure 2. Transverse sections of extensor digitorum longus muscle $4 \mathrm{~h}$ after receiving $\mathrm{A}: 50$ $\mu \mathrm{l} \mathrm{NaCl}$ injections, B: $0.25 \mu \mathrm{g} / \mathrm{g}$ of venom, and C: $2.0 \mu \mathrm{g} / \mathrm{g}$ of venom. A, Panoramic view of control muscle showing normal cells and organization. In B note the lesion of peripheral muscle fibers and the disorganization of the bundles. In C note the complete degeneration of muscle fibers $(\mathrm{bar}=110 \mu \mathrm{m})$.

\section{References}

1. Ownby CL, Gutiérrez J M, Colberg TR \& Odell GV (1982). Quantitation of myonecrosis induced by myotoxin a from prairie rattlesnake (Crotalus viridis viridis) venom. Toxicon, 20: 877-885.

2. Mebs $D$, Ehrenfeld $M \&$ Samejima $Y$ (1983). Local necrotizing effect of snake venoms on skin and muscle: relationship to serum creatine kinase. Toxicon, 21: 393-404.

3. Ownby CL \& Colberg TR (1986). Ability of polyvalent (Crotalidae) antivenom to neutralize local myonecrosis induced by Crotalus atrox venom. Toxicon, 24: 201-203.

4. Gutierrez J M, Chaves $F$ \& Cerdas L (1986). Inflammatory infiltrate in skeletal muscle injected with Bothrops asper venom. Revista de Biologia Tropical, 34: 209-214.
5. Ownby CL \& Colberg TR (1988). Classification of myonecrosis induced by snake venoms: venoms from the prairie rattlesnake (Crotalus viridis viridis), western diamondback rattlesnake (Crotalus atrox) and the Indian cobra (Naja naja naja). Toxicon, 26: 459-474.

6. Lomonte B, Gutierrez JM, Romero M, Nunez J, Tarkowski A \& Hanson LA (1993). An MTT-based method for the in vivo quantification of myotoxic activity of snake venoms and its neutralization by antibodies. J ournal of Immunological Methods, 161: 231-237.

7. Melo PA \& Suarez-Kurtz G (1987). Interaction of Bothrops venoms and antivenin on the release of creatine kinase from skeletal muscle. Brazilian J ournal of Medical and Biological Research, 20: 821-824.
8. Melo PA \& Suarez-Kurtz G (1988). Release of sarcoplasmic enzymes from skeletal muscle by Bothrops jararacussu venom: antagonism by heparin and by serum of south American marsupials. Toxicon, 26: 87-95.

9. Melo PA, Nascimento MC, Mors WB \& Suarez-Kurtz G (1994). Inhibition of the myotoxic and hemorrhagic activities of crotalid venoms by Eclipta prostrata (Asteraceae) extracts and constituents. Toxicon, 32: 595-603.

10. Melo PA, Homsi-Brandeburgo MI, Giglio J R \& Suarez-Kurtz G (1993). Antagonism of the myotoxic effects of Bothrops jararacussu venom and bothrops toxin by polyanions. Toxicon, 31: 285-291. 